\title{
Process Disturbances in Agricultural Biogas Production-Causes, Mechanisms and Effects on the Biogas Microbiome: A Review
}

\author{
Susanne Theuerl ${ }^{1, * \mathbb{C}}$, Johanna Klang ${ }^{1}$ and Annette Prochnow ${ }^{1,2}$ (i) \\ 1 Leibniz Institute for Agricultural Engineering and Bioeconomy, Max-Eyth-Allee 100, \\ 14469 Potsdam, Germany; jklang@atb-potsdam.de (J.K.); aprochnow@atb-potsdam.de (A.P.) \\ 2 Humboldt Universität zu Berlin, Albrecht Daniel Thaer Institute for Agricultural and Horticultural Sciences, \\ Hinter der Reinhardtstr. 6-8, 10115 Berlin, Germany \\ * Correspondence: susanne.theuerl@googlemail.com; Tel.: +49-331-5699-900
}

Received: 20 December 2018; Accepted: 19 January 2019; Published: 24 January 2019

\begin{abstract}
Disturbances of the anaerobic digestion process reduce the economic and environmental performance of biogas systems. A better understanding of the highly complex process is of crucial importance in order to avoid disturbances. This review defines process disturbances as significant changes in the functionality within the microbial community leading to unacceptable and severe decreases in biogas production and requiring an active counteraction to be overcome. The main types of process disturbances in agricultural biogas production are classified as unfavorable process temperatures, fluctuations in the availability of macro- and micronutrients (feedstock variability), overload of the microbial degradation potential, process-related accumulation of inhibiting metabolites such as hydrogen $\left(\mathrm{H}_{2}\right)$, ammonium/ammonia $\left(\mathrm{NH}_{4}{ }^{+} / \mathrm{NH}_{3}\right)$ or hydrogen sulphide $\left(\mathrm{H}_{2} \mathrm{~S}\right)$ and inhibition by other organic and inorganic toxicants. Causes, mechanisms and effects on the biogas microbiome are discussed. The need for a knowledge-based microbiome management to ensure a stable and efficient production of biogas with low susceptibility to disturbances is derived and an outlook on potential future process monitoring and control by means of microbial indicators is provided.
\end{abstract}

Keywords: anaerobic digestion; biogas; microbial biodiversity; process control

\section{Introduction}

One of the main challenges to optimize biogas production is to achieve high process stability and efficiency with low susceptibility to disturbances [1-6]. Process disturbances reduce the economic and environmental performance of biogas systems since they lead to decreased methane yields and hence reduce revenues, net energy yields and greenhouse gas emissions mitigation and result in additional expenditures for remedy. Consequently, there is the need to better understand the causes, mechanisms and effects of process instabilities and disturbances, especially the response of the biogas microbiome in order to avoid them.

Given that the anaerobic digestion plant is technically fully operational (e.g., regarding digester technology, mechanic feeding, temperature regulation, and stirring or pumping systems), all instabilities and disturbances of the digestion process are attributed to malfunctioning of the biogas microbiome induced by the operator's management measures. The objective of this review is to define process instabilities and disturbances while classifying different types, their causes, mechanisms and effects on the microbial community. Additionally, an outlook on potential future process monitoring and control strategies by means of using microbial indicators to deduce strategies for a sustainable 
microbial diversity management will be provided. The focus of this review is on agricultural biogas production where the plants are mainly operated by farmers and run on the basis of agricultural residues (e.g., livestock manure), energy crops (e.g., maize, grass, sugar beet) and partly residues from the food industry and biorefineries.

\section{The Biogas Microbiome}

Biogas digesters are highly sensitive technological-biological systems with a diverse and complex interacting microbial community that converts anaerobically degradable biomass into biogas. The process can be roughly divided into the four main steps hydrolysis, acidogenesis, acetogenesis and methanogenesis whereby the metabolites of one step are the precursors for the next step (Figure 1). These steps run simultaneously as the involved microorganisms with their different physiological capacities depend on each other's degradation products and require a close spatial proximity.

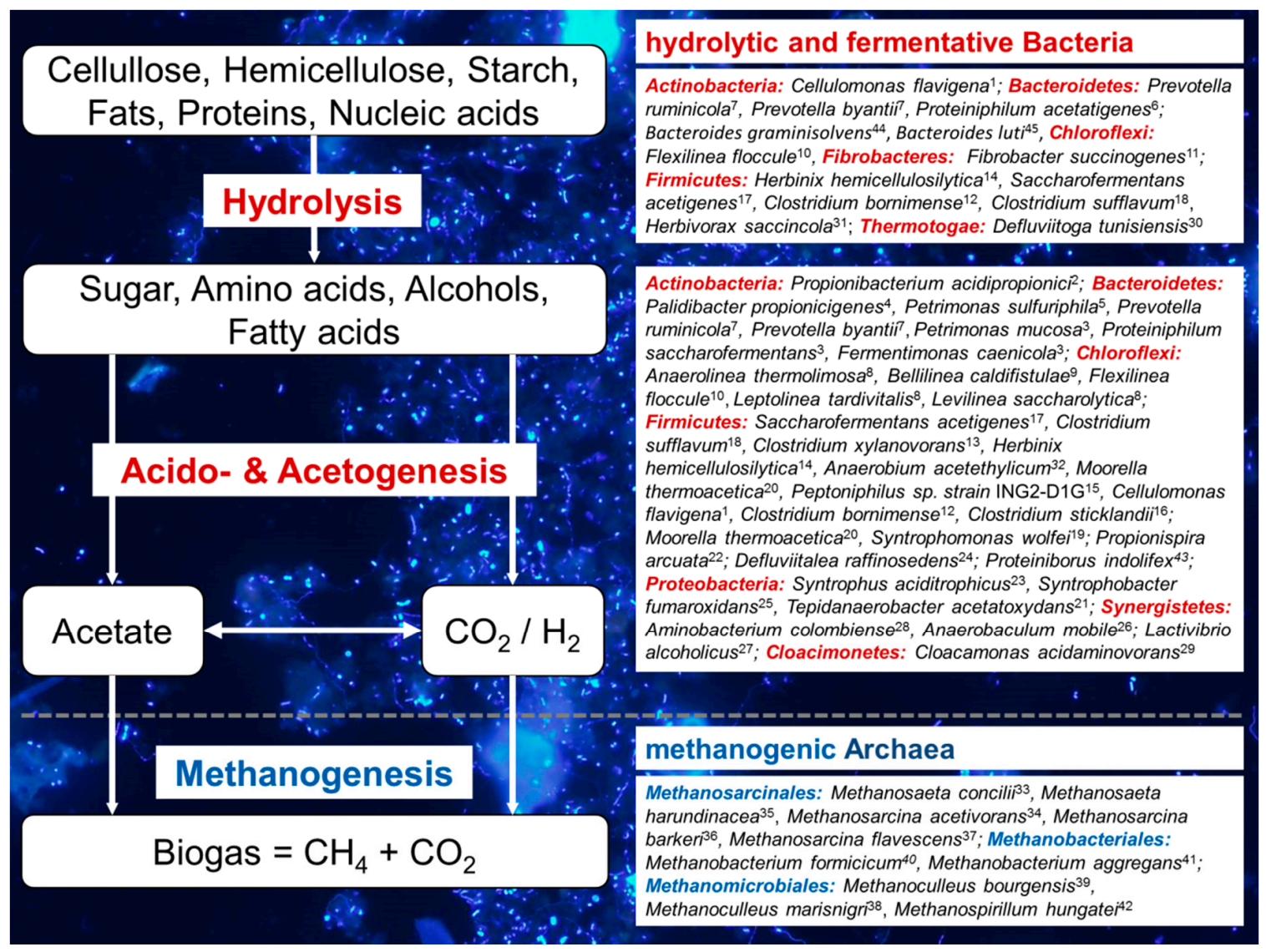

Figure 1. Compilation of the currently physiologically and/or genetically described microorganisms putatively involved in the different steps of the anaerobic digestion process. The corresponding reference list is given in Supplement 1. The microscopic image in the background shows a biogas microbiome stained with DAPI (4',6-diamidino-2-phenylindole) of an anaerobic digester treating a mixture of energy crops and animal manure (photo by J. Klang). $\mathrm{CO}_{2}=$ carbon dioxide, $\mathrm{H}_{2}=$ hydrogen, $\mathrm{CH}_{4}=$ methane.

So far, the most investigated species of the biogas microbiome are hydrolytic and fermentative bacteria and methanogenic archaea. Figure 1 shows a compilation of the physiologically and/or genetically described microorganisms involved in the different steps of the anaerobic digestion process.

The biogas microbiome does not only comprise bacteria and archaea but also viruses/phages [7] as well as eukaryotes including fungi and protists (mainly protozoa) which are less investigated [8-10]. While it is assumed that the functional characteristics of pro- and eukaryotes are closely related to 
each other in a cooperative way [11], viruses/phages are suspected to have regulatory effects on the microbial cell turnover $[7,12]$.

The current state of knowledge on the biogas microbiome can be characterized by three general statements:

- Despite intensive research and growing knowledge on the microbiome most of the species and hence their ecological functions are still unknown [13-15].

- Each anaerobic digester develops its own specific microbiome [16-18].

- Most individuals of the biogas microbiome are generalists which are able to exist under various conditions, hence being found in most of the biogas plants and with regard to their abundance making the largest part of the community. In contrast, most species are specialists which occupy specific ecological niches, are detected only in few samples and are often specific to the digester. (In 20 anaerobic digestion plants a total number of 5938 bacterial operational taxonomic units (OUT) were detected. Only $2.5 \%$ (around 150 OTUs) were assigned to the biogas core microbiome with a median relative abundance of $70.3 \% \pm 12.5 \%$ (the generalists), whereas $84.0 \%$ (around 5000 OTUs) were only found in a certain number of samples representing $3.5 \% \pm 3.8 \%$ of the relative bacterial abundances (the specialists) [16]).

The microbial diversity in anaerobic digesters is affected by the plant operator's management as this influences the microbiome's living conditions (Figure 2). The nutritional basis for the microorganisms is provided by the feedstocks. Their chemical composition and physical characteristics affect the bioavailability/bioaccessibility of the anaerobically degradable compounds. The chosen type, amount and possibly pretreatment of feedstocks determine the available amount of macroand micronutrients. The abiotic environment of the microorganisms is formed by the digester technology (e.g., continuously stirred/plug flow/container, one/two-phase) and the digester operation (e.g., loading rate, retention time or process temperature). When designing the abiotic environment of the biogas microbiome it has to be considered that each population (sum of individuals of a respective species in a habitat) of the biogas microbiome does not only have different optima regarding its living requirements, but also different tolerance levels against environmental factors. If these environmental factors exceed or fall below certain thresholds process disturbances might occur.

These management options shape the biogas microbiome which is characterized by its taxonomic, functional and ecological diversity (Figure 2). The taxonomic diversity covers the number and distribution of occurring species. The functional diversity defines the potential (i.e., genetically determined) and the actually realized functions and processes of the occurring species. The ecological diversity describes interactions of the microorganisms among each other and with their environment. The more we are able to understand and quantitatively describe the ecological functions of biogas microbiomes in their complexity, the more we will be able to deduce reliable and reproducible forecasts how systems react to varying external influences and how the performance of biogas microbiomes can be optimized and sustainably used for a knowledge-based process control. This in turn will enable us to better use the biogas microbiome technically to the benefit of human and environment (adapted from [19]).

In order to establish a sustainable microbial diversity management strategy for anaerobic digestions systems, the question that still has to be answered is "Who does what, when, with whom and why?" $[5,8,14,20-23]$. Moreover, there is an urgent need to better understand the taxonomic, functional and ecological difference between well-performing and disturbed microbiomes. 


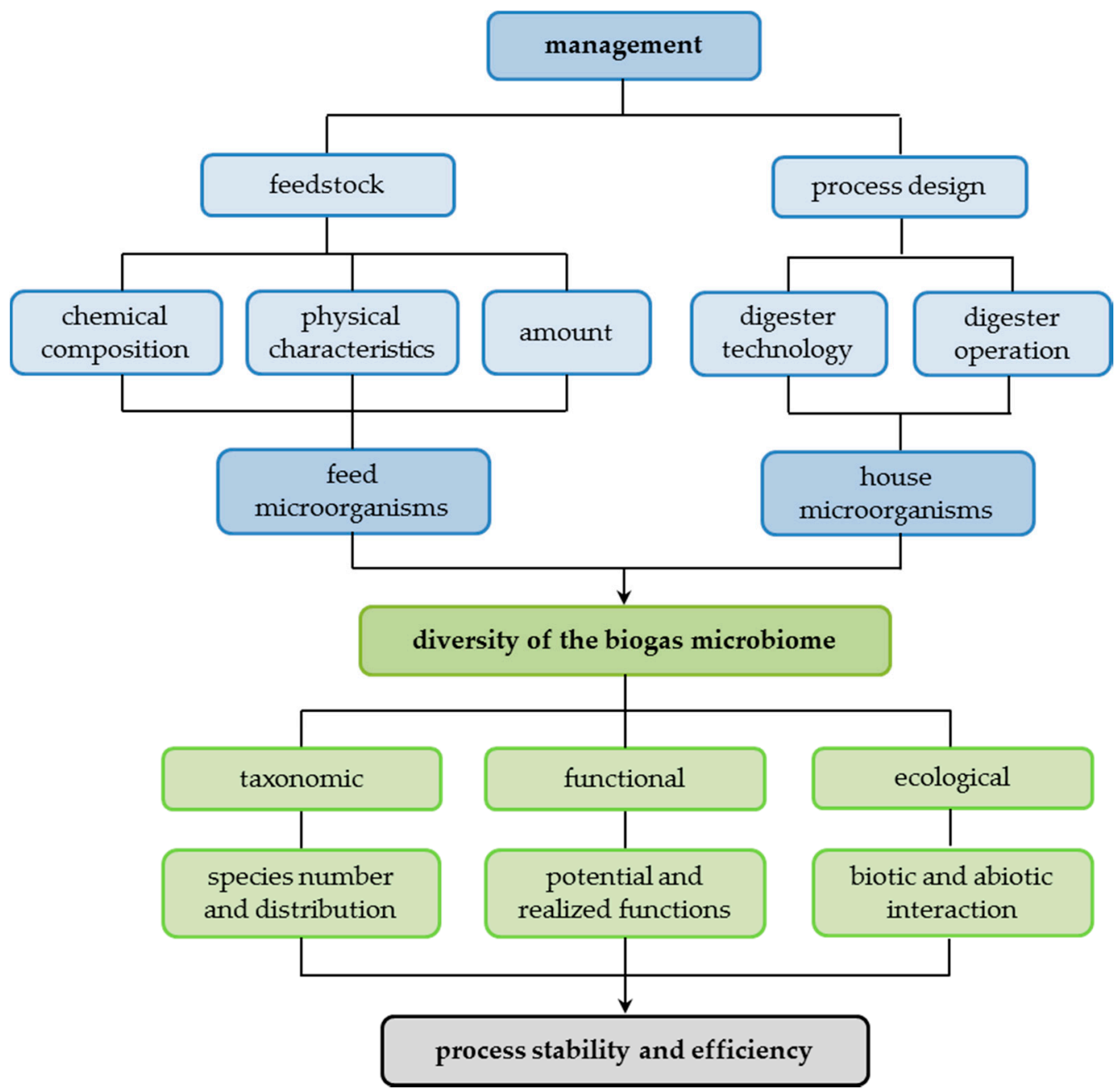

Figure 2. Management of the anaerobic digestion process and diversity levels of the biogas microbiome.

\section{Types of Process Instabilities and Disturbances}

\subsection{Definition and Overview}

The general definition of a disturbance is a temporary event that significantly changes the normal state of a system. With specific regard to the anaerobic digestion of biomass to biogas we here define a process disturbance as a significant change in the functionality within the microbial community leading to severe and unaccepted decreases in biogas/methane generation and requiring counteraction to be overcome. To which extent a decrease is accepted or not is at the discretion of the plant operator. Since plant operators will decide mainly with regard to profitability, the accepted extent of the disturbance depends on the respective relation of costs and revenues [24].

We distinguish process instabilities from disturbances as temporary changes in the functionality within the microbial community that cause slight decreases in biogas/methane generation whereby the microbiome is able to reorganize itself without active counteraction of the plant operator.

The response of microbiomes or of populations within the microbiome to process disturbances can be described using three basic concepts [25]: (i) the microbiome can be resistant, meaning the microbiome withstands a disturbance without changing its taxonomic, functional and ecologic composition, (ii) the microbiome is resilient, which means that the microbiome composition returns back to its original composition after being disturbed, and (iii) members of the microbiome are functional redundant whereby inhibited community members can be replaced by others with similar function. 
Instabilities and disturbances of the anaerobic digestion process may have manifold causes with different underlying mechanisms [26-29]. The main types occurring in agricultural biogas production can be classified as follows:

- unfavorable process temperatures,

- fluctuations in the availability of macro- and micronutrients (feedstock variability),

- overload of the microbial degradation potential,

- process-related accumulation of inhibiting metabolites such as hydrogen $\left(\mathrm{H}_{2}\right)$, ammonium/ammonia $\left(\mathrm{NH}_{4}{ }^{+} / \mathrm{NH}_{3}\right)$ or hydrogen sulphide $\left(\mathrm{H}_{2} \mathrm{~S}\right)$,

- inhibition by other organic and inorganic toxicants, e.g., light metal ions, heavy metals, chlorophenols, halogenated aliphatics, long chain fatty acids, nanomaterials, antibiotics, or viruses.

In practice it is nearly impossible to relate an instability or disturbance to one single cause/factor; mostly it is a combination of various factors that leads to process instabilities or disturbances (Figure 3). In the next sections, causes, mechanisms and effects on the biogas microbiome for the first four categories of the above mentioned disturbances are discussed. The last category is less intensively investigated in agricultural biogas production, especially regarding the response of the microbiome, and will not be discussed in detail here.
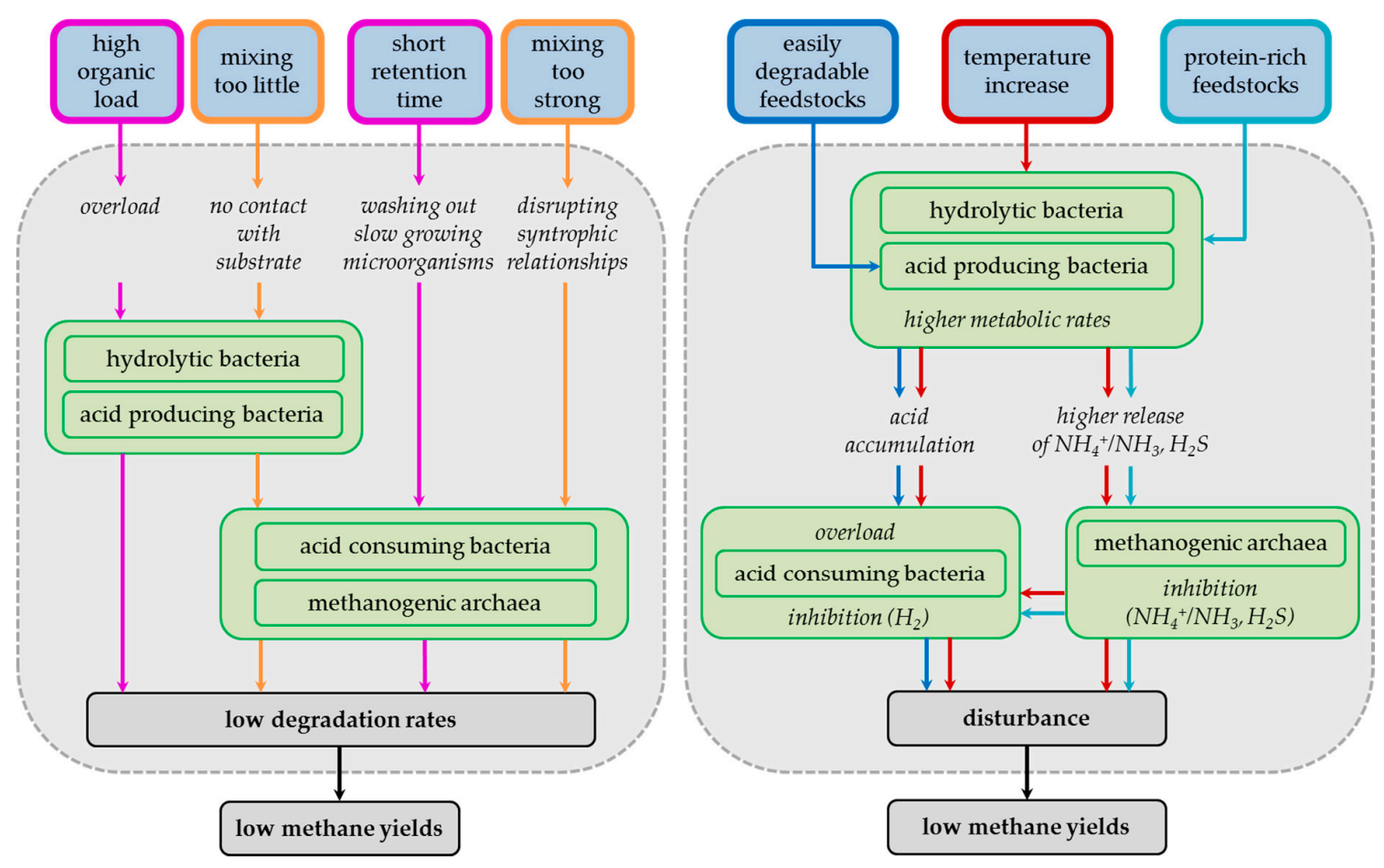

Figure 3. Causes, mechanisms and effects of process disturbances on the biogas microbiome (dashed line-microbial system; blue boxes-management measures causing process disturbances; green boxes-microorganisms affected in the four steps of the digestion process; colored arrows-cause-effect chains of disturbance types).

So far, no studies are available on process disturbances in full-scale anaerobic digesters which investigate the dynamics of a process disturbance from the beginning to the end, distinguishing the "disturbed" microbiome from the "normal/healthy" or "recovered" microbiome in order to identify process-relevant microorganisms. This can mainly be attributed to the fact that process disturbances in full-scale biogas plants cannot be reasonably induced due to the high operation costs and potential economic losses. Moreover, process disturbances cannot be predicted. Consequently, studies on process disturbances in full-scale anaerobic digesters depend on randomly occurring events challenged 
by the "search" for instabilities/disturbances directly at the right time and place when and where the disturbances occur. Hence, such studies are case studies where the results cannot be validated or reproduced. Because of this, most studies and hence most knowledge on process disturbances originate from model digestion systems as they offer a broad spectrum of options to manipulate the process under controlled conditions.

\subsection{Unfavorable Process Temperatures}

Temperature is one of the most important environmental factors affecting growth and metabolic activity of microorganisms [6,18,30-33]. For the process of anaerobic digestion, biomass degradation accelerates with increasing temperatures and hence per time unit more biomass is converted into biogas due to higher reaction rates (Figure 3) [6,33]. However, it has to be considered that the members of the biogas microbiome are metabolically active within certain ranges of temperature, so that changes in the temperature regime lead to a change in the microbial community composition and ecological function while mesophilic digesters show a higher microbial diversity then thermophilic digesters $[18,30,34]$. Many agricultural anaerobic digesters (especially in Germany) are operated at $40-45^{\circ} \mathrm{C}$, which is between the optimal ranges for mesophilic $\left(33-38^{\circ} \mathrm{C}\right)$ and thermophilic $\left(50-60^{\circ} \mathrm{C}\right)$ conditions $[6,18,31]$.

The temperature in anaerobic digesters should be changed slowly to enable the microbial community to adapt to the new environmental conditions. Strong fluctuations or fast increases or decreases carry the risk of process instabilities (Figure 3). This is well shown in an experiment which investigated how a change in the temperature regime influences the process stability, the potential for process optimization and the microbial community structure [6]. A temperature increase from $37^{\circ} \mathrm{C}$ to $52{ }^{\circ} \mathrm{C}$ or a decrease from $52{ }^{\circ} \mathrm{C}$ to $37^{\circ} \mathrm{C}$ was performed stepwise by $2{ }^{\circ} \mathrm{C}$ per week. The digester with decreasing temperature showed the most unstable process. During the temperature change acetate and propionate concentrations were high and methane yields low. The digester with increasing temperature operated more stable, but temporary disturbances still occurred when passing the range between 40 and $44{ }^{\circ} \mathrm{C}$. These results are in accordance with previous findings [31]. At the microbial level a temperature sensitivity of members of the phylum Cloacimonetes was found. They disappeared when the temperature increase passed the $40-44{ }^{\circ} \mathrm{C}$ range [6]. Similar findings have been reported previously [35] indicating that this microbial group might be a suitable process indicator for upcoming process disturbances due to an inappropriate temperature regime.

As mentioned above, a temperature increase leads to an increased metabolic activity and hence to higher degradation rates with an accelerated release of organic acids and other process-inhibiting metabolites such as ammonium/ammonia $\left(\mathrm{NH}_{4}{ }^{+} / \mathrm{NH}_{3}\right)$ or hydrogen sulphide $\left(\mathrm{H}_{2} \mathrm{~S}\right)$ (see Section 3.6), making the process less stable. Hence, for a permanent or temporary thermophilic digester operation a knowledge-based management of the microbiome is necessary.

\subsection{Fluctuation of Nutrient Availability}

\subsubsection{Feedstocks as Nutritional Basis}

The feedstocks are the nutritional basis for the biogas microbiome. The macro- and micronutrients within the feedstocks affect microbial growth and activity and hence the degradation kinetics and the biogas/methane yield [10,36,37]. An optimal nutrient supply is essential for a stable digestion process. That means, the feedstock composition should (i) meet the nutritional requirements of the digester's microbiome, (ii) result in high biogas and methane yield and (iii) lead to a high quality digestate [10].

The availability of the macro- and micronutrients for the microbial community changes depending on the amount, composition and quality of the feedstocks as well as on the general process performance $[18,30,38,39]$. The main reasons for fluctuating nutrient availability are variation of the feedstock supply and insufficient mixing of the digester's content. 


\subsubsection{Chemical Composition of the Feedstocks}

The chemical composition and the bioaccessibility of the feedstocks determine the potential amount of biogas/methane that can be produced [29]. The theoretical biogas yield from carbohydrates, fats and proteins are 750, 1390 and 800 norm liters per kg organic dry mass with theoretical methane amounts of $50 \%, 72 \%$ and $60 \%$ [33]. The amount and bioavailability of macro- and micronutrients varies strongly in different feedstocks. As different microorganisms have different nutrient requirements and also different degradation capacities to certain feedstock compounds, the chemical complexity of the supplied feedstock (either various compounds or complex molecule structures) directly affects the diversity of the biogas microbiome [18].

Anaerobic digesters operated with easily convertible feedstocks such as sugar beet silage or chemically stable/similar feedstocks (in function of time), such as wastewater sludge and industrial wastes show less diverse microbial communities. Several studies have shown that these communities are often dominated by members of the phylum Bacteroidetes, especially from the order Bacteroidales [18,30,38,40-43]. Most of the so far described members of this phylum are known for rapid conversion of easily degradable sugars and alcohols into acids e.g., [44-49] which indicates that they play a crucial role in acidogenesis and acetogenesis.

In contrast, feedstocks such as biowaste, energy crops and livestock manure are chemically more complex and/or heterogeneous in function of time. Their conversion needs a structural more diverse community with members of various phyla (e.g., Firmicutes, Bacteroidetes, Chloroflexi, Proteobacteria, Spirochaetes, Synergistetes, Thermotogae, Cloacimonetes as well as Euryarchaeota) e.g., [18,30,38,43,50-52]. Such communities are enabled to successively, complementarily and efficiently degrade most of the bioavailable/bioaccessible feedstock compounds (except the anaerobically hardly-degradable lignin $[51,53]$ ) due to a high functional and ecological diversity (broad range of metabolic pathways, generalists, specialists, redundancy, resilience, concurrence, syntrophy, co-occurrence). As chemically more complex feedstocks often feature high lignocellulose contents, pretreatment techniques are applied in order to enhance rheology, degradability and hence biogas/methane production [52,54-56]. Some pretreatment techniques, mainly chemical ones, are known to generate toxic compounds $[55,57]$ which have to be expected to cause inhibitory effects in the subsequent digestion process. Many studies deal with the impact of various pretreatment techniques on methane yields, but so far it has not been investigated how the pretreated feedstocks affect the diversity of the biogas microbiome and hence the process performance.

If the feedstock type changes, the microbial communities need to adapt to the new conditions, not only with respect to their taxonomic composition, but above all regarding their predominant functions and ecological behavior. Changing the feedstock does not necessarily have negative impacts on biogas production, but should be applied with caution. For example, a stepwise increase of poultry manure to a basic mixture of cattle slurry and solid manure led to altered nutrient supply and hence changing environmental conditions causing process instability. Without taking countermeasures, the microbiome reconstructed over a period of approximately 100 days [58] (see also Section 3.6). The new microbial community was functionally redundant as similar biogas/methane yields were recorded after the disturbance. From an ecological point of view, this can be called a naturally controlled microbial diversity management.

\subsubsection{Nutrient Distribution}

It is well known that a good stirring/mixing of the digester's content is of high importance to evenly spread fresh feedstock material within the digester, to ensure a close contact between the substrates (i.e., the nutrients supplied with the feedstocks) and the degrading microorganisms, to facilitate the removal of end products of metabolism and the upflow of gas bubbles, as well as to achieve even temperature conditions across the digester $[33,59,60]$.

Depending on the kind of feedstock, insufficient mixing (low mixing intensity) might lead to stratification of the digester content. Light material tends to float on the surface (floating layer 
formation) while heavier material sinks to the bottom (sedimentation) [60]. Consequently, the contact area between microorganisms and their substrates is disrupted (Figure 3). In case of a floating layer formation, the contact area is restricted to the boundary zone of the solid phase (the biodegradable material) and the liquid phase where most of the microorganisms are located. Hence, only a small fraction of the nutrients is accessible to the microorganisms causing low degradation rates.

On the other hand, too high mixing intensities are detrimental to the biogas production as the required close contact between acid oxidation bacteria and their methanogenic partners is interrupted (Figure 3) [60,61].

Although stirring/mixing of the digester content is of high importance, little is known about the effects of stirring/mixing at the microbial level. Further research should investigate the effects of stirring on the microbiome at the different stages of anaerobic digestion [60], as this could be one option to manage the process efficiency by regulating the contact between the microorganisms and their nutrients and hence regulate the biogas flux.

\subsection{Overload of the Microbial Degradation Potential}

The digestion process becomes overloaded when the biomass input (amount of organic material added per active reactor volume and day) exceeds the degradation capacity of the biogas microbiome. This situation may occur for instance at too high organic loading rates in combination with too short retention times $[10,40,62-64]$. This leads to insufficient degradation rates and low biogas/methane yields in proportion to the amount of the supplied biomass (Figure 3). While the hydraulic retention time defines the medium duration of the feedstocks in the digester, the solids retention time describes the available time for the microorganisms to establish in the digester [65].

When the retention time is too short, which is typically the case with increasing the organic loading rate, microbial biomass cannot establish in required amounts to degrade the supplied biomass which might cause a wash-out of microorganisms resulting in a loss of essential functions for the ecosystem (Figure 3) $[10,64,65]$. Hence, organic load can only be increased when the retention time is long enough to ensure a certain reproduction (growth) and spreading time for the microorganisms to meet their function. This applies in particular to the slowly-growing acid-degrading and methanogenic members of the community. Thus, for a stable process performance, retention times of more than 10 days are generally recommended [66,67].

An overload of the process can also occur when the formation of one metabolic intermediate exceeds the degrading capacity of the microorganisms involved in the subsequent step. This can be caused by insufficient mixing of the digester's content, changing feedstock regimes, increasing temperature or inhibition of specific microbial populations by $\mathrm{NH}_{3}, \mathrm{H}_{2} \mathrm{~S}$ or $\mathrm{H}_{2}$.

Overloads often are related to acid accumulation (Figure 3), indicating an imbalance of microbial acid producers and consumers $[40,63,68,69]$. The underlying mechanism is based on different ways of obtaining energy and consequently on different growth rates: a thermodynamically more favorable energy production results in faster growth rates of the microorganisms [70-73].

While the energy balance of most hydrolytic and acidogenic reactions is negative - meaning a direct energy gain for the microorganisms - the reactions of acid-degrading microorganisms are thermodynamically unfavorable and require more energy than they yield [70,71,74]. Acid-degrading microorganisms often live in syntrophy with hydrogen scavengers, in the biogas process ideally hydrogenotrophic archaea, due to the fact that the conversion of most fatty acids is only possible via the formation of hydrogen $\left(\mathrm{H}_{2}\right)$. Without subsequent $\mathrm{H}_{2}$ utilization by $\mathrm{H}_{2}$ scavengers such as hydrogenotrophic archaea or homoacetogens, the acid-degrading bacteria would be inhibited by their own metabolic end product [73]. However, the overall energy balance becomes negative and proceeds with a low energy gain for both partners (see Section 3.5).

With regard to an acid accumulation, this means that the biomass is relatively quickly converted into acids which can often be assigned to an increased relative abundance of members of the phylum Bacteroidetes $[40,63,69]$, but the acids cannot be converted into biogas in the same time frame due to the 
slower growth rates of the acid-degrading microorganisms [63]. This is of high importance and should be carefully considered while operating a biogas plant, especially under thermophilic conditions with a less diverse microbiome (Figure 3). From an ecological point of view, microbiomes with a high diversity level are assumed to be more stress resistant/resilient due to a higher metabolic potential and hence a high functional redundancy resulting in a higher stress tolerance potential according to increasing organic loads or even overloads $[4,69]$.

Although it is well known that high loading rates (in combination with short retention times) have to be handled with caution, the entire regulatory processes-including the response of the microbiome or of its members - is still not fully understood, which hampers the recommendation of respective management strategies to efficiently control the process.

\subsection{Hydrogen Inhibition}

High amounts of $\mathrm{H}_{2}$ may indicate a disturbance of the microbial community equilibrium. Methanogenic archaea are only capable to use acetic acid, $\mathrm{H}_{2}$ and one-carbon (C1) compounds, such as carbon dioxide $\left(\mathrm{CO}_{2}\right)$ [75]. This means that C3-C6 fatty acids (propionic acid, butyric acid, succinic acid, and lactic acid) formed during acidogenesis, first have to be converted into utilizable compounds $[70,74,76]$. This is carried out by bacteria, such as members of the genera Syntophomonas, Syntrophobacter, Syntrophus, Propionibacter, Pelotomaculum, Smithella or Clostridium, who live in syntrophy with hydrogenotrophic archaea $[70,74]$. Syntrophy, in general terms, is an association of different microorganisms who mutually provide and use intermediates to and from the other partner and hence are interdependent for survival [73-78]. By the combined metabolic activity of microorganisms, endergonic reactions can become exergonic through the efficient removal of products and therefore enable a microbial community to survive with minimal energy resources [70,74].

Due to the lack of suitable electron acceptors, the conversion of fatty acids is often only possible via the formation of high-calorific $\mathrm{H}_{2}[70,74,77,78]$. As mentioned above, without subsequent utilization of the generated $\mathrm{H}_{2}$ by hydrogen scavengers, the syntrophic bacteria would be inhibited by their own end product since excessive $\mathrm{H}_{2}$ concentrations make the fatty acid oxidation thermodynamically impossible [73]. It follows that hydrogen scavengers (e.g., hydrogenotrophic archaea) depend on the $\mathrm{H}_{2}$ which is produced by their neighboring bacteria who in turn can only grow, if the $\mathrm{H}_{2}$ is consumed. Consequently, an inhibition of the function of hydrogen scavengers, such as hydrogenotrophic archaea by $\mathrm{NH}_{4}{ }^{+} / \mathrm{NH}_{3}$ or $\mathrm{H}_{2} \mathrm{~S}$ inhibition, leads to a process disturbance which is reflected not only in reduced methane yields, but also in acid accumulation (Figure 3, see Sections 3.4 and 3.6).

In this context syntrophic acetate oxidation is a particularly well investigated process that occurs under certain environmental conditions. The energy balance of acetate oxidation is quite unfavorable (free Gibb's energy $\left(\Delta G^{\circ \prime}\right)=+104.6 \mathrm{~kJ} \cdot \mathrm{mol}^{-1}$ ). Together with hydrogenotrophic partners the energy balance improves to $\Delta G^{\circ \prime}=-31 \mathrm{~kJ} \cdot \mathrm{mol}^{-1}\left(\Delta G^{\circ \prime}=-15.5 \mathrm{~kJ} \mathrm{~mol}{ }^{-1}\right.$ per partner), whereby the $\mathrm{H}_{2}$ partial pressure should be limited to the range 1.6 to $6.8 \mathrm{~Pa}$ under mesophilic conditions [79,80]. Due to the highly complex requirements of syntrophic microorganisms for their living conditions, they can hardly be cultivated and hence their genetic, physiologic and ecological characterization is limited. Bacteria currently known to be capable of syntrophic acetate oxidation are Thermacetogenium phaeum, Pseudothermotoga lettingae, Tepidanaerobacter acetatoxydans, Clostridium ultunense and Syntrophaceticus schinkii [80].

Moreover, there are indications that high partial pressure of $\mathrm{H}_{2}$ also negatively affects hydrolysis. An observed decrease in the degradation of wheat straw without acid accumulation (the metabolites from acidogenic bacteria) indicates that the hydrolytic activity (the first process step) was inhibited [81]. $\mathrm{H}_{2}$ inhibition at the hydrolysis stage could be suppressed through the addition of $\mathrm{CO}_{2}$ [81].

\subsection{Ammonium/Ammonia and Hydrogen Sulphide Inhibition}

The anaerobic digestion of feedstock with high nitrogen contents, such as grass silage, poultry manure or slaughterhouse waste, may negatively affect the function of the microbial 
community and hence biogas and methane generation (Figure 3). A critical issue is the formation of ammonium $\left(\mathrm{NH}_{4}^{+}\right)$which is generated during the degradation of proteins, nucleic acids and/or uric acid/urea and cannot be further degraded under anaerobic conditions [80,82-86]. In aqueous solutions $\mathrm{NH}_{4}{ }^{+}$is in equilibrium with $\mathrm{NH}_{3}$, which shifts towards $\mathrm{NH}_{3}$ with increasing temperature and $\mathrm{pH}$. Generally, it is assumed that microorganisms, e.g., methanogenic archaea, might be affected "in two ways: (i) the ammonium ion $\left(\mathrm{NH}_{4}^{+}\right)$may inhibit the methane producing enzymes directly and / or (ii) the hydrophobic ammonia molecule $\left(\mathrm{NH}_{3}\right)$ may diffuse passively into the microbial cells, causing proton imbalance or potassium deficiency" [84].

Methanogenic archaea generate methane either by converting acetic acid (acetoclastic methanogenesis) or by using hydrogen $\left(\mathrm{H}_{2}\right)$ and carbon dioxide $\left(\mathrm{CO}_{2}\right)$ (hydrogenotrophic methanogenesis) [75]. The obligate acetoclastic methanogens (members of the family Methanothrix) have the narrowest ranges of tolerance to $\mathrm{NH}_{4}{ }^{+}$and $\mathrm{NH}_{3}$ e.g., [84,87-89]. Frequently described and generally accepted thresholds for concentrations of $\mathrm{NH}_{4}{ }^{+}$range from 3 to $5 \mathrm{~g} \mathrm{~L}^{-1}$ and of $\mathrm{NH}_{3}$ from 80 to $400 \mathrm{mg} \mathrm{L}^{-1}[80,84]$. With rising concentrations of $\mathrm{NH}_{4}{ }^{+}$and/or $\mathrm{NH}_{3}$, changes in the taxonomic and hence the functional diversity within the archaeal community are recorded e.g., [58,83,90,91].

For example, in a long-term, lab-scale experiment the impact of increasing amounts of poultry manure and accordingly increasing $\mathrm{NH}_{4}{ }^{+} / \mathrm{NH}_{3}$ concentration on the microbial diversity was investigated [58]. During the second experimental phase the addition of $50 \%$ poultry manure (based on VS) led to a serious process instability with a total acid concentration of $9.6 \mathrm{~g} \mathrm{~L}^{-1}$ at $5.9 \mathrm{~g} \mathrm{NH}_{4}{ }^{+} \mathrm{L}^{-1}$ and $500 \mathrm{mg} \mathrm{NH} \cdot \mathrm{L}^{-1}$, which resulted in a decrease of the methane yield by $25 \%$. Over the course of the instability, while operating the digester at constant conditions, the dominating bacterial order shifted from Bacteroidetes to Clostridiales, combined with a change from acetoclastic to hydrogenotrophic methanogenesis. With similar overall process rates after the disturbance, the adapted microbiome was functional redundant [58]. Similar results regarding the microbiome reorganization were published previously e.g., [83,90-93]. However, another study investigated the impact of different ammonium sources (animal manure and ammonium carbonate) to reveal whether there is a relation between the microbial diversity level (structure and function) and the stress tolerance potential of the microbial community [90]. It was shown that a sugar beet silage digesting bacterial community with a pre-dominance of members from the phylum Bacteroidetes associated with a functionally flexible archaeal community (mainly Methanotrix, Methanosarcina, Methanoculleus), was more stress resistant under the certain experimental conditions, than a maize silage digesting community with a more diverse and evenly distributed bacterial community associated with a rigid archaeal community (mainly Methanotrix). This indicates that a higher taxonomic and hence functional diversity at a certain community part, in the presented study the archaeal community, is one important factor for process stability.

Furthermore, members of the bacterial phylum Cloacimonetes were reported to disappear with increasing $\mathrm{NH}_{4}{ }^{+} / \mathrm{NH}_{3}$ concentrations [6,90]. Especially in the study by Klang et al. [90], the relative abundance decreased more than 50 days prior to a process disturbance. In consequence, the disappearance of these microorganisms might be a potential indicator for upcoming process disturbances caused by increasing total ammonium nitrogen (sum of $\mathrm{NH}_{4}{ }^{+}$and $\mathrm{NH}_{3}$ ) concentrations.

As already mentioned and several times reported, obligate acetoclastic methanogens (members of the family Methanotrix) are most sensitive against elevated $\mathrm{NH}_{4}{ }^{+} / \mathrm{NH}_{3}$ concentrations. If acetic acid cannot directly be converted into methane due to $\mathrm{NH}_{4}{ }^{+} / \mathrm{NH}_{3}$ inhibition of the respective microbial group, the community uses the pathway of syntrophic acetate oxidation (see Section 3.5). Here, the acetic acid is converted into $\mathrm{CO}_{2}$ and $\mathrm{H}_{2}$ via the inverse homoacetogenesis and further converted into methane by hydrogenotrophic archaea $[79,80]$. Based on the results of different studies, the threshold for the syntrophic acetate oxidation is limited to the range 140 to $250 \mathrm{mg} \mathrm{NH}_{3} \mathrm{~L}^{-1}$ (approximately 3.0 to $3.3 \mathrm{~g} \cdot \mathrm{NH}_{4}{ }^{+} \mathrm{L}^{-1}$ ) at a temperature of $37^{\circ} \mathrm{C}$ and a $\mathrm{pH}$ from 7.5 to 8.0 [80].

Another example for a process-related accumulation of inhibiting metabolites is the production of hydrogen sulphide $\left(\mathrm{H}_{2} \mathrm{~S}\right)$ (Figure 3). Since $\mathrm{H}_{2} \mathrm{~S}$ is produced by the degradation of proteins, or, 
more precisely, of sulphur-containing amino acids, such as cysteine and methionine, an increased amount of $\mathrm{H}_{2} \mathrm{~S}$ can be expected if protein-rich feedstocks, such as grass silage, slaughterhouse waste or biowaste, are used [18]. $\mathrm{H}_{2} \mathrm{~S}$ has a toxic effect on methanogenic archaea (Figure 3), as it diffuses through the cell membrane and denatures proteins within the cell, leading to inhibition of enzymes $[65,94,95]$. $\mathrm{H}_{2} \mathrm{~S}$ also reacts with metal ions. The precipitation of, for example, chromium $(\mathrm{Cr})$ or nickel $(\mathrm{Ni})$, which are essential as enzyme cofactors, is an indirect form of inhibition of methanogenesis by $\mathrm{H}_{2} \mathrm{~S}[37,95]$. Although it is quite known that $\mathrm{H}_{2} \mathrm{~S}$ can lead to process disturbances due to the inhibition of the most important functional group of the biogas microbiome, the methanogenic archaea [28,82], little is known about the underlying microbial mechanisms. De Jonge et al. [94] investigated the reaction of a microbial community to a prolonged starvation time and the subsequent process reactivation under thermophilic conditions. A large shift within the acetogenic and methanogenic communities was observed, which was attributed to a strong increase in the volatile fatty acids (VFA), $\mathrm{NH}_{4}{ }^{+} / \mathrm{NH}_{3}$ as well as $\mathrm{H}_{2} \mathrm{~S}$ concentration. However, this topic still needs further research, especially regarding the causes, mechanisms and effects on the biogas microbiome.

\subsection{Further Potential Causes for Process Instabilities/Disturbances}

There are several other potential causes for process instabilities/disturbances which partly enter the system with the feedstock supply (e.g., heavy metals, organic toxicants, antibiotics), while others are by-products originated during the break down of biomass (e.g., light metals, trace elements, long chain fatty acids) or which are part of the native biogas microbiome, like viruses $[7,12,37,53,82,96-101]$ Yet, little is known about the underlying mechanisms and how they affect the biogas microbiome.

For instance, is it well known that salts (or better the cations of salts, light metal ions such as $\mathrm{Na}^{+}, \mathrm{K}^{+}, \mathrm{Mg}^{2+}, \mathrm{Ca}^{2+}, \mathrm{Al}^{3+}$ ) are required for microbial growth and activity like any other nutrient, but high salt levels can also lead to process instabilities/disturbances as they cause dehydration of microbial cells due to osmotic pressure [82]. In the case of potential salt stress, it has often been described that conductivity values above $30 \mathrm{mS} \mathrm{cm}^{-1}$ indicate unfavorable process conditions which are related to variations in the microbial diversity [18,82,102]. Also heavy metals $(\mathrm{Cu}, \mathrm{Zn}, \mathrm{Pb}, \mathrm{Hg}$, $\mathrm{Cr}, \mathrm{Cd}, \mathrm{Fe}, \mathrm{Ni}, \mathrm{Co}, \mathrm{Mo}$ ) are important trace elements and a certain amount is required for microbial growth and activity. $\mathrm{Fe}, \mathrm{Ni}$ and $\mathrm{Co}$, for example, are considered to be most essential in anaerobic digestion as they are important cofactors in enzyme systems in the methane formation pathway. Consequently, a certain amount of trace elements can have a stimulating effect on the anaerobic digestions, e.g., by increasing the volatile fatty acid utilization even at elevated TAN concentration of up to $7.2 \mathrm{~g} \mathrm{~L}^{-1}$ while mono-digesting chicken manure [103]. Moreover, trace elements also act as a binding component in sulfide precipitation and hence can be used to control the level of $\mathrm{H}_{2} \mathrm{~S}$ [37,104]. On the other hand $\mathrm{H}_{2} \mathrm{~S}$ has a negative impact on the trace element bioavailability since trace elements are often immobilized in sulfides, especially in anaerobic digestion with a redox potential of $-300 \mathrm{mV}$ and neutral $\mathrm{pH}$ [37]. This in turn indirectly inhibits the process (see Section 3.6). However, in practice heavy metals (trace elements) are often supplemented in excessive amounts to anaerobic digesters. As they are non-biodegradable, their accumulation can inhibit acetogens, acidogens as well as methanogens [37,96]. While methanogens are assumed to be most sensitive to changes in trace element speciation and bioavailability, knowledge on the effects of trace elements on the other anaerobic trophic groups is still lacking [37].

In addition, some recent studies show inhibitory effects of organic compounds such as lignin derivates [53], humic acids [99,101], or coumarin, a metabolite derived from the anaerobic conversion, e.g., of grassland biomass $[105,106]$. The underlying mechanisms of inhibition are still unknown. It is assumed that humic acids prevent cellulose degradation by binding to the corresponding hydrolytic enzymes [99,101].

Besides these examples for abiotic factors, there are also biotic factors which might cause process instabilities/disturbances. Significant correlations were shown between the occurrence of phages and prokaryotes over time at the $\alpha$ - and $\beta$-diversity level: $40.6 \%$ of total prokaryotic community 
variation was explained by the abundance of phages, in comparison to only $14.5 \%$ by abiotic factors [12]. This study showed that phages and the prokaryotic communities are highly interconnected, which might be in turn responsible for process stability or even instabilities as phages are one reason for prokaryotic cell lyses. This indicates that biotic factors should be much more considered for process or better microbiome control in the future.

\section{Perspectives of a Future Microbial Process Monitoring and Control}

To ensure a stable and efficient biogas production, regular process monitoring is standard nowadays. This does not only provide insights into the general process performance, it also provides the opportunity to detect/recognize process instabilities/disturbances [28,29]. Yet, today's process control is still based on technical and chemical parameters and on the experience of the biogas plant operators (Table 1) $[8,20]$ resulting in various process enhancing strategies such as pretreatment of feedstocks [52,55,56], optimization of the digester technology [107], optimization of operational parameters [29,108] as well as the supplementation of additives [107]. Although the production of biogas would be impossible without microorganisms, process control based on microbial diversity parameters is still missing.

Table 1. Overview on indicators commonly used to monitor process stability and efficiency (compiled from [27-29]). Given are the indicators, the direct or indirect information on the process as well as efforts which are required for their measurements. $\mathrm{CH}_{4}=$ methane, VFA = volatile fatty acids, $\mathrm{NH}_{4}{ }^{+}=$ammonium, $\mathrm{NH}_{3}=$ ammonia.

\begin{tabular}{ccc}
\hline Indicator & Direct or Indirect Information on & Measuring Effort \\
\hline feedstock composition & nutrient availability & high, laboratory \\
temperature & metabolic performance & low, thermometer \\
amount of produced biogas ${ }^{1)}$ & process performance & low, online-sensors \\
biogas composition & process performance, $\mathrm{CH}_{4}$ content & low, online-sensors \\
hydrogen $\left(\mathrm{H}_{2}\right)$ & inhibition of methanogenesis & low, online-sensors \\
hydrogen sulphide $\left(\mathrm{H}_{2} \mathrm{~S}\right)$ & inhibition of methanogenesis & low, online-sensors \\
redox potential & reaction conditions & low, redox electrodes \\
conductivity & salt concentration & low, electrical sensors \\
pH value ${ }^{2)}$ & acid accumulation (yes $/$ no) & low, pH electrodes \\
VFA concentration ${ }^{3)}$ & system overload & high, laboratory \\
$\mathrm{VFA} \mathrm{spectrum}_{\mathrm{NH}_{4}{ }^{+}-\mathrm{N} / \mathrm{NH}_{3}}$ & concentration of single acids & high, laboratory \\
\hline
\end{tabular}

\footnotetext{
${ }_{1}^{1}$ Significance of this parameter for the prediction of process instabilities/disturbances is questionable, because the process is already disturbed when the amount of biogas decreases; ${ }^{2}$ Useful indicator in digesters with low buffering capacity, but low informative value to predict process instabilities/disturbances in well-buffered systems, ${ }^{3}$ Nowadays several spectral sensors are available for on-line measurement of volatile fatty acids (VFA), but prices are still far too expensive [29].
}

Nearly all recent studies describe the effects of environmental parameters on the microbial community structure. One important research challenge is the reversed approach for exploring the influence of the microbial community on the digester functioning and stability [2,5]. Most chemical parameters which indicate process instabilities/disturbances (e.g., acid accumulation, elevated $\mathrm{NH}_{4}{ }^{+} / \mathrm{NH}_{3}, \mathrm{H}_{2} \mathrm{~S}$, or $\mathrm{H}_{2}$ concentrations) result from previous microbial activities (see Figure 3 ). A proactive approach should be developed for process control and management, to detect upcoming instabilities/disturbances earlier in the cause-effect-chain, i.e., not only at the metabolic products that have been produced, but already at the microbiome.

To achieve this, it is essential to better understand the anaerobic microbiome, including the metabolic capacities of the occurring microorganisms and the fundamental mechanisms for biotic and abiotic interactions in a temporal dimension $[8,10,20,109,110]$. The application of modern sequencing tools, including $16 \mathrm{~S}$ ribosomal ribonucleic acid (rRNA) gene amplicon libraries as well as metagenome, metatranscriptome, and metaproteome analyses has led to many new and deeper insights in the 
microbial diversity of anaerobic digestion plants e.g., [13,14,26,109-113]. However, similar as in other fields of microbiome research, 'omic' techniques only display snapshots of the microbial diversity at a certain time under certain conditions and provide limited information about community dynamics or ecological behavior [114], especially on the response of single species, groups of microorganisms or entire microbiomes to varying environmental factors over time. Hence, established techniques, such as the terminal restriction fragment length polymorphism (TRFLP), are still valuable for microbiome screening in full-scale biogas plants, in particular with respect to microbial process monitoring [64,80,115-118]. The disadvantage of this method, however, is a low phylogenetic resolution, so that the identification of indicator species is not completely possible. New sequencing technologies [119], such as Nanopore sequencing, are expected to overcome this limitation by the possibility to elucidate microbial diversity with high phylogenetic resolution down to the species level by full-length sequencing of the 16S rRNA gene in high temporal resolution [26,120,121].

Additionally, most of the occurring microorganisms are only known by their $16 \mathrm{~S}$ rRNA gene sequence (or by a reconstructed whole genome sequence), but they are not yet cultivable and hence cannot be comprehensively described regarding their actually realized ecological functions $[13,15,16,109,110]$. This highlights that the metabolic potential of the anaerobic digestion process has not reached its limits yet, and that further optimization of the process is still to discover [4].

To optimize the process, the potentials and, above all, the limitations of the performance of the ecosystem "anaerobic digester" have to be defined and new methods, that assess the adaptability and resilience of microbial populations to specific environmental conditions, have to be developed. The fundamental challenge is to quantitatively describe and understand the biogas microbiome in its complexity and to predict its response to external influences. This can be made by co-occurrence network analyses which (i) provide an integrated vision of all the relationships existing between microorganisms in a given environmental matrix, (ii) show that in the case of disturbance, interactions are the first to be affected and thus alter the functions of the ecosystem even before the species disappear and (iii) deliver the opportunity to define keystone species within a complex environment $[109,122,123]$.

Currently, the available tools for detecting the microbial diversity are highly complex regarding sample preparation and especially data evaluation and interpretation [109-111]. Identifying microbial indicators is a precondition for developing rapid and economical microbial detection methods to be used by plant operators and consultants. With regard to this, an efficient indicator needs to be (i) robust, reliable and accurate while it reflects the current process status and remains stable and coherent over time, (ii) sensitive and specific to reflect even weak variations (imbalances, disturbances) in the environment or system over time and space, (iii) straightforward to measure and understand, with easy interpretation by comparing with a suitable reference system, (iv) acceptable considering the cost-benefit ratio and (v) relevant to facilitate decision-making [27,109,123].

This is of particular importance for future process control and management strategies, as there are indications that specific microbiome members (e.g., members of the phylum Cloacimonetes) probably can be used as indicators for upcoming process disturbances $[6,90]$. Further research is needed to identify potential microbial indicators and their ranges of tolerance regarding process conditions and to develop detection methods for practical application.

The concept to use microbial species and their abundances for monitoring, assessing and managing processes has already been applied in several fields such as hygiene [124], food safety [125] or ecology [126]. With the advances in microbiome research, the approach to use single species and/or microbial diversity parameters as indicators is also considered for other areas such as soil quality $[127,128]$, crop health and productivity $[129,130]$ or human health [131]. The conditions for successful identification, development and application of microbial indicators seem promising in anaerobic digestion since it is a closed system with a high potential to control environmental factors and reveal their interactions with the microbiome. 
Supplementary Materials: The following are available online at http:/ /www.mdpi.com/1996-1073/12/3/365/s1. The reference list for Figure 1 is available as Supplement 1.

Author Contributions: S.T.; A.P.; and J.K. developed the concept. S.T. wrote the major parts of the manuscript. A.P. wrote parts of the manuscript. A.P. and J.K. revised the manuscript.

Funding: The work of Susanne Theuerl and Johanna Klang has been funded by the German Federal Ministry of Food and Agriculture and managed by the Agency for Renewable Resources under grants FKZ 22013913 and FKZ 22403915.

Acknowledgments: The authors thank Mareike Lausberg for language check and text editing. The authors kindly thank the Open Access Fund of the Leibniz Association for funding the publication of this article.

Conflicts of Interest: The authors declare no conflict of interest. The authors declare that the research was conducted in the absence of any commercial or financial relationships that could be construed as a potential conflict of interest.

\section{References}

1. Bensmann, A.; Hanke-Rauschenbach, R.; Heyer, R.; Kohrs, F.; Benndorf, D.; Kausmann, R.; Plöchl, M.; Heiermann, M.; Reichl, U.; Sundmacher, K. Diagnostic concept for dynamically operated biogas production plants. Renew. Energy 2016, 96, 479-489. [CrossRef]

2. Carballa, M.; Regueiro, L.; Lema, J.M. Microbial management of anaerobic digestion: Exploiting the microbiome-functionality nexus. Curr. Opin. Biotechnol. 2015, 33, 103-111. [CrossRef] [PubMed]

3. De los Reyes, F.L., III; Weaver, J.E.; Wang, L. A methodological framework for linking bioreactor function to microbial communities and environmental conditions. Curr. Opin. Biotechnol. 2015, 33, 112-118. [CrossRef]

4. De Vrieze, J.; Verstraete, W. Perspectives for microbial community composition in anaerobic digestion: From abundance and activity to connectivity. Environ. Microbiol. 2016, 18, 2797-2809. [CrossRef] [PubMed]

5. Venkiteshwaran, K.; Bocher, B.; Maki, J.; Zitomer, D. Relating anaerobic digestion microbial community and process function. Microbiol. Insights 2016, 8, 37-44. [CrossRef] [PubMed]

6. Westerholm, M.; Isaksson, S.; Karlsson Lindsjö, O.; Schnürer, A. Microbial community adaptability to altered temperature conditions determines the potential for process optimisation in biogas production. Appl. Energy 2018, 226, 838-848. [CrossRef]

7. Calusinska, M.; Marynowska, M.; Goux, X.; Lentzen, E.; Delfosse, P. Analysis of dsDNA and RNA viromes in methanogenic digesters reveals novel viral genetic diversity. Environ. Microbiol. 2016, 18, 1162-1175. [CrossRef] [PubMed]

8. Castellano-Hinojosa, A.; Amato, C.; Pozo, C.; González-Martínez, A.; González-López, J. New concepts in anaerobic digestion processes: Recent advances and biological aspects. Appl. Microbiol. Biotechnol. 2018, 102, 5065-5076. [CrossRef] [PubMed]

9. Dollhofer, V.; Callaghan, T.M.; Griffith, G.W.; Lebuhn, M.; Bauer, J. Presence and transcriptional activity of anaerobic fungi in agricultural biogas plants. Bioresour. Technol. 2017, 235, 131-139. [CrossRef] [PubMed]

10. Schnürer, A. Biogas Production: Microbiology and Technology. In Anaerobes in Biotechnology; Advances in Biochemical Engineering/Biotechnology; Hatti-Kaul, R., Mamo, G., Mattiasson, B., Eds.; Springer: Cham, Switzerland, 2016; Volume 156, pp. 195-234. ISBN 978-3-319-45651-5.

11. Matsubayashi, M.; Shimada, Y.; Li, Y.-Y.; Harada, H.; Kubota, K. Phylogenetic diversity and in situ detection of eukaryotes in anaerobic sludge digesters. PLoS ONE 2017, 12, e0172888. [CrossRef]

12. Zhang, J.; Gao, Q.; Zhang, Q.; Wang, T.; Yue, H.; Wu, L.; Shi, J.; Qin, Z.; Zhou, J.; Zuo, J.; et al. Bacteriophage-prokaryote dynamics and interaction within anaerobic digestion processes across time and space. Microbiome 2017, 5, 57. [CrossRef] [PubMed]

13. Hassa, J.; Maus, I.; Off, S.; Pühler, A.; Scherer, P.; Klocke, M.; Schlüter, A. Metagenome, metatranscriptome, and metaproteome approaches unraveled compositions and functional relationships of microbial communities residing in biogas plants. Appl. Microbiol. Biotechnol. 2018, 102, 5045-5063. [CrossRef] [PubMed]

14. Kundu, K.; Sharma, S.; Sreekrishnan, T.R. Influence of process parameters on anaerobic digestion microbiome in bioenergy production: Towards an improved understanding. Bioenergy Res. 2017, 10, 288-303. [CrossRef]

15. Treu, L.; Kougias, P.G.; Campanaro, S.; Bassani, I.; Angelidaki, I. Deeper insight into the structure of the anaerobic digestion microbial community; the biogas microbiome database is expanded with 157 new genomes. Bioresour. Technol. 2016, 216, 260-266. [CrossRef] [PubMed] 
16. Calusinska, M.; Goux, X.; Fossépré, M.; Muller, E.E.L.; Wilmes, P.; Delfosse, P. A year of monitoring 20 mesophilic full-scale bioreactors reveals the existence of stable but different core microbiomes in bio-waste and wastewater anaerobic digestion systems. Biotechnol. Biofuels 2018, 11, 196. [CrossRef] [PubMed]

17. Mei, R.; Nobu, M.K.; Narihiro, T.; Kuroda, K.; Muñoz Sierra, J.; Wu, Z.; Ye, L.; Lee, P.K.H.; Lee, P.H.; van Lier, J.B.; et al. Operation-driven heterogeneity and overlooked feed-associated populations in global anaerobic digester microbiome. Water Res. 2017, 124, 77-84. [CrossRef] [PubMed]

18. Theuerl, S.; Klang, J.; Heiermann, M.; De Vrieze, J. Marker microbiome clusters are determined by operational parameters and specific key taxa combinations in anaerobic digestion. Bioresour. Technol. 2018, 263, $128-135$. [CrossRef]

19. German Federal Ministry of Food and Agriculture (Bundesministerium für Bildung und Forschung). National Research Stategy BioEconomy 2013-Our way to a Bio-Based Economy (Nationale Forschungsstrategie BioÖkonomie 2030-Unser Weg zu einer bio-basierten Wirtschaft); German Federal Ministry of Food and Agriculture (Bundesministerium für Bildung und Forschung): Berlin, Germany, 2010.

20. De Vrieze, J.; Christiaens, M.E.R.; Verstraete, W. The microbiome as engineering tool: Manufacturing and trading between microorganisms. New Biotechnol. 2017, 39, 206-214. [CrossRef]

21. Marzorati, M.; Wittebolle, L.; Boon, N.; Daffonchio, D.; Verstraete, W. How to get more out of molecular fingerprints: Practical tools for microbial ecology. Environ. Microbiol. 2008, 10, 1571-1581. [CrossRef]

22. Read, S.; Marzorati, M.; Guimarães, B.C.M.; Boon, N. Microbial Resource Management revisited: Successful parameters and new concepts. Appl. Microbiol. Biotechnol. 2011, 90, 861-871. [CrossRef]

23. Verstraete, W.; Wittebolle, L.; Heylen, K.; Vanparys, B.; de Vos, P.; van de Wiele, T.; Boon, N. Microbial Resource Management: The Road to Go for Environmental Biotechnology. Eng. Life Sci. 2007, 7, 117-126. [CrossRef]

24. Theuerl, S.; Klang, J.; Prochnow, A. Prozessstörungen in landwirtschaftlichen Biogasanlagen-Ursachen, Mechanismen und Auswirkungen auf das Biogas-Mikrobiom. In Proceedings of the KTBL/FNR-Kongress: Biogas in der Landwirtschaft-Stand und Perspektiven, Bayreuth, Germany, 26-27 September 2017.

25. Allison, S.D.; Martiny, J.B. Resistance, resilience, and redundancy in microbial communities. Proc. Natl. Acad. Sci. USA 2008, 105, 11512-11519. [CrossRef] [PubMed]

26. Amha, Y.M.; Anwarb, M.Z.; Brower, A.; Jacobsen, C.S.; Stadler, L.B.; Webster, T.M.; Smith, A.L. Inhibition of anaerobic digestion processes: Applications of molecular tools. Bioresour. Technol. 2018, 247, 999-1014. [CrossRef] [PubMed]

27. Boe, K.; Batstone, D.J.; Steyer, J.P.; Angelidaki, I. State indicators for monitoring the anaerobic digestion process. Water Res. 2010, 44, 5973-5980. [CrossRef] [PubMed]

28. Drosg, B. Process monitoring in biogas plants. In IEA Bioenergy Task 37-Energy from Biogas; Frost, P., Baxter, D., Eds.; IEA Bioenergy: Paris, France, 2013; ISBN 978-1-910154-03-8.

29. Jimenez, J.; Latrille, E.; Harmand, J.; Robles, A.; Ferrer, J.; Gaida, D.; Wolf, C.; Mairet, F.; Bernard, O.; Alcaraz-Gonzalez, V.; et al. Instrumentation and control of anaerobic digestion processes: A review and some research challenges. Rev. Environ. Sci. Biotechnol. 2015, 14, 615-648. [CrossRef]

30. De Vrieze, J.; Saunders, A.M.; He, Y.; Fang, J.; Nielsen, P.H.; Verstraete, W.; Boon, N. Ammonia and temperature determine potential clustering in the anaerobic digestion microbiome. Water Res. 2015, 75, 312-323. [CrossRef]

31. Kim, J.; Lee, C. Response of a continuous anaerobic digester to temperature transitions: A critical range for restructuring the microbial community structure and function. Water Res. 2016, 89, 241-251. [CrossRef]

32. Luo, G.; De Francisci, D.; Kougias, P.G.; Treu, L.; Zhu, X.; Angelidaki, I. New steady-state microbial community compositions and process performances in biogas reactors induced by temperature disturbances. Biotechnol. Biofuels 2015, 8, 3. [CrossRef]

33. Weiland, P. Biogas production: Current state and perspectives. Appl. Microbiol. Biotechnol. 2010, 85, 849-860. [CrossRef]

34. Sundberg, C.; Al-Soud, W.A.; Larsson, M.; Alm, E.; Yekta, S.S.; Svensson, B.H.; Sørensen, S.J.; Karlsson, A. 454 pyrosequencing analyses of bacterial and archaeal richness in 21 full-scale biogas digesters. FEMS Microbiol. Ecol. 2013, 85, 612-626. [CrossRef]

35. Regueiro, L.; Carballa, M.; Lema, J.M. Outlining microbial community dynamics during temperature dropand subsequent recovery period in anaerobic co-digestion systems. J. Biotechnol. 2014, 192, 179-186. [CrossRef] [PubMed] 
36. Li, Y.; Zhang, R.; Liu, G.; Chen, C.; He, Y.; Liu, X. Comparison of methane production potential, biodegradability, and kinetics of different organic substrates. Bioresour. Technol. 2013, 149, 565-569. [CrossRef] [PubMed]

37. Thanh, P.M.; Ketheesan, B.; Yan, Z.; Stuckey, D. Trace metal speciation and bioavailability in anaerobic digestion: A review. Biotechnol. Adv. 2016, 34, 122-136. [CrossRef] [PubMed]

38. Klang, J.; Theuerl, S.; Szewzyk, U.; Huth, M.; Tölle, R.; Klocke, M. Dynamic variation of the microbial community structure during the long-time mono-fermentation of maize and sugar beet silage. Microb. Biotechnol. 2015, 8, 764-775. [CrossRef] [PubMed]

39. Zhang, W.; Werner, J.J.; Agler, M.T.; Angenent, L.T. Substrate type drives variation in reactor microbiomes of anaerobic digesters. Bioresour. Technol. 2014, 151, 397-401. [CrossRef] [PubMed]

40. Goux, X.; Calusinska, M.; Lemaigre, S.; Marynowska, M.; Klocke, M.; Udelhoven, T.; Benizri, E.; Delfosse, P. Microbial community dynamics in replicate anaerobic digesters exposed sequentially to increasing organic loading rate, acidosis, and process recovery. Biotechnol. Biofuels 2015, 8, 122-140. [CrossRef] [PubMed]

41. Kirkegaard, R.H.; Mcllroy, S.J.; Kristensen, J.M.; Nierychlo, M.; Karst, S.M.; Dueholm, M.S.; Albertsen, M.; Nielsen, P.H. The impact of immigration on microbial community composition in full-scale anaerobic digesters. Sci. Rep. 2017, 7, 9343. [CrossRef] [PubMed]

42. Ward, A.J.; Hobbs, P.J.; Holliman, P.J.; Jones, D.L. Optimisation of the anaerobic digestion of agricultural resources. Bioresour. Technol. 2008, 99, 7928-7940. [CrossRef] [PubMed]

43. Werner, J.J.; Knights, D.; Garcia, M.L.; Scalfone, N.B.; Smith, S.; Yarasheski, K.; Cummings, T.A.; Beers, A.R.; Knight, R.; Angenent, L.T. Bacterial community structures are unique and resilient in full-scale bioenergy systems. Proc. Natl. Acad. Sci. USA 2011, 108, 4158-4163. [CrossRef] [PubMed]

44. Chassard, C.; Delmas, E.; Lawson, P.A.; Bernalier-Donadille, A. Bacteroides xylanisolvens sp. nov., a xylan-degrading bacterium isolated from human faeces. Int. J. Syst. Evol. Microbiol. 2008, 58, 1008-1013. [CrossRef] [PubMed]

45. Chen, S.; Dong, X. Proteiniphilum acetatigenes gen. nov., sp. nov., from a UASB reactor treating brewery wastewater. Int. J. Syst. Evol. Microbiol. 2005, 55, 2257-2261. [CrossRef] [PubMed]

46. Grabowski, A.; Tindall, B.J.; Bardin, V.; Blanchet, D.; Jeanthon, C. Petrimonas sulfuriphila gen. nov., sp. nov., a mesophilic fermentative bacterium isolated from a biodegraded oil reservoir. Int. J. Syst. Evol. Microbiol. 2005, 55, 1113-1121. [CrossRef] [PubMed]

47. Hahnke, S.; Langer, T.; Koeck, D.E.; Klocke, M. Description of Proteiniphilum saccharofermentans sp. nov., Petrimonas mucosa sp. nov. and Fermentimonas caenicola gen. nov., sp. nov., isolated from mesophilic laboratory-scale biogas reactors, and emended description of the genus Proteiniphilum. Int. J. Syst. Evol. Microbiol. 2016, 66, 1466-1475. [CrossRef] [PubMed]

48. Jabari, L.; Gannoun, H.; Cayol, J.-L.; Hedi, A.; Sakamoto, M.; Falsen, E.; Ohkuma, M.; Hamdi, M.; Fauque, G.; Ollivier, B.; et al. Macellibacteroides fermentans gen. nov., sp. nov., a member of the family Porphyromonadaceae isolated from an upflow anaerobic filter treating abattoir wastewaters. Int. J. Syst. Evol. Microbiol. 2012, 62, 2522-2527. [CrossRef] [PubMed]

49. Ueki, A.; Akasaka, H.; Suzuki, D.; Ueki, K. Paludibacter propionicigenes gen. nov., sp. nov., a novel strictly anaerobic, Gram-negative, propionate producing bacterium isolated from plant residue in irrigated rice-field soil in Japan. Int. J. Syst. Evol. Microbiol. 2006, 56, 39-44. [CrossRef] [PubMed]

50. Azman, S.; Khadem, A.F.; van Lier, J.B.; Zeeman, G.; Plugge, C.M. Presence and role of anaerobic hydrolytic microbes in conversion of lignocellulosic biomass for biogas production. Crit. Rev. Environ. Sci. Technol. 2014, 45, 2523-2564. [CrossRef]

51. Li, W.; Khalid, H.; Zhu, Z.; Zhang, R.; Liu, G.; Chen, C.; Thorin, E. Methane production through anaerobic digestion: Participation and digestion characteristics of cellulose, hemicellulose and lignin. Appl. Energy 2018, 226, 1219-1228. [CrossRef]

52. Shrestha, S.; Fonoll, X.; Khanal, S.K.; Raskin, L. Biological strategies for enhanced hydrolysis of lignocellulosic biomass during anaerobic digestion: Current status and future perspectives. Bioresour. Technol. 2017, 245, 1245-1257. [CrossRef]

53. Mulat, D.G.; Horn, S.J. Biogas Production from Lignin via Anaerbic digestion. In Lignin Valorization: Emerging Approaches; Beckham, G.T., Ed.; Energy and Environment Series; Royal Society of Chemistry (RSC) Publishing: Cambridge, UK, 2018; pp. 391-412. ISBN 978-1-78262-554-4. 
54. Budzianowski, W.M. A review of potential innovations for production, conditioning and utilization of biogas with multiple-criteria assessment. Renew. Sustain. Energy Rev. 2016, 54, 1148-1171. [CrossRef]

55. Carrère, H.; Antonopoulou, G.; Affes, R.; Passos, F.; Battimelli, A.; Lyberatos, G.; Ferrer, I. Review of feedstock pretreatment strategies for improved anaerobic digestion: From lab-scale research to full-scale application. Bioresour. Technol. 2016, 199, 386-397. [CrossRef]

56. Montgomery, L.F.R.; Bochmann, G. Pretreatment of feedstock for enhanced biogas production. In IEA Bioenergy Task 37-Energy from Biogas; Baxter, D., Ed.; IEA Bioenergy: Paris, France, 2014; ISBN 978-1-910154-05-2.

57. Jönsson, L.J.; Martín, C. Pretreatment of lignocellulose: Formation of inhibitory by-products and strategies for minimizing their effects. Bioresour. Technol. 2016, 199, 103-112. [CrossRef]

58. Alsouleman, K.; Linke, B.; Klang, J.; Klocke, M.; Krakat, N.; Theuerl, S. Reorganisation of a mesophilic biogas microbiome as response to a stepwise increase of ammonium nitrogen induced by poultry manure supply. Bioresour. Technol. 2016, 208, 200-204. [CrossRef]

59. Kobayashi, T.; Wu, Y.-P.; Xu, K.-Q.; Li, Y.-Y. Effect of mixing driven by siphon flow: Parallel experiments using the anaerobic reactors with different mixing modes. Energies 2013, 6, 4207-4222. [CrossRef]

60. Lindmark, J.; Thorin, E.; Bel Fdhila, R.; Dahlquist, E. Effects of mixing on the result of anaerobic digestion: Review. Renew. Sustain. Energy Rev. 2014, 40, 1030-1047. [CrossRef]

61. McMahon, K.D.; Stroot, P.G.; Mackie, R.I.; Raskin, L. Anaerobic codigestion of municipal solid waste and biosolids under various mixing conditions-II: Microbial population dynamics. Water Res. 2001, 35, 1817-1827. [CrossRef]

62. De Vrieze, J.; Verstraete, W.; Boon, N. Repeated pulse feeding induces functional stability in anaerobic digestion. Microb. Biotechnol. 2013, 6, 414-424. [CrossRef] [PubMed]

63. Regueiro, L.; Lema, J.M.; Carballa, M. Key microbial communities steering the functioning of anaerobic digesters during hydraulic and organic overloading shocks. Bioresour. Technol. 2015, 197, 208-216. [CrossRef] [PubMed]

64. Ziganshin, A.M.; Schmidt, T.; Lv, Z.; Liebetrau, J.; Richnow, H.H.; Kleinsteuber, S.; Nikolausz, M. Reduction of the hydraulic retention time at constant high organic loading rate to reach the microbial limits of anaerobic digestion in various reactor systems. Bioresour. Technol. 2016, 217, 62-71. [CrossRef]

65. Gerardi, M.H. The Microbiology of Anaerobic Digesters; Wiley: Hoboken, NJ, USA, 2003; ISBN 978-0-471206-93-4.

66. Ju, F.; Lau, F.; Zhang, T. Linking microbial community, environmental variables, and methanogenesis in anaerobic biogas digesters of chemically enhanced primary treatment sludge. Environ. Sci. Technol. 2017, 51, 3982-3992. [CrossRef]

67. Nguyen, L.N.; Nguyen, A.Q.; Nghiem, L.D. Microbial community in anaerobic digestion system: Progression in microbial ecology. In Water and Wastewater Treatment Technologies; Bui, X.T., Chiemchaisri, C., Fujioka, T., Varjani, S., Eds.; Energy, Environment, and Sustainability Book Series; Springer: Singapore, 2019; pp. 331-355, ISBN print 978-981-13-3258-6, ISBN online 978-981-13-3259-3.

68. Hori, T.; Haruta, S.; Sasaki, D.; Hanajima, D.; Ueno, Y.; Ogata, A.; Ishii, M.; Igarashi, Y. Reorganization of the bacterial and archaeal populations associated with organic loading conditions in a thermophilic anaerobic digester. J. Biosci. Bioeng. 2015, 119, 337-344. [CrossRef]

69. Li, Y.-F.; Abraham, C.; Nelson, M.C.; Chen, P.-H.; Graf, J.; Yu, Z. Effect of organic loading on the microbiota in a temperature-phased anaerobic digestion (TPAD) system co-digesting dairy manure and waste whey. Appl. Microbiol. Biotechnol. 2015, 99, 8777-8792. [CrossRef] [PubMed]

70. Leng, L.; Yang, P.; Singh, S.; Zhuang, H.; Xu, L.; Chen, W.-H.; Dolfing, J.; Li, D.; Zhang, Y.; Zeng, H.; et al. A review on the bioenergetics of anaerobic microbial metabolism close to the thermodynamic limits and its implications for digestion applications. Bioresour. Technol 2018, 247, 1095-1106. [CrossRef] [PubMed]

71. Montag, D.; Schink, B. Biogas process parameters-Energetics and kinetics of secondary fermentations in methanogenic biomass degradation. Appl. Microbiol. Biotechnol. 2016, 100, 1019-1026. [CrossRef] [PubMed]

72. Roden, E.E.; Jin, Q. Thermodynamics of microbial growth coupled to metabolism of glucose, ethanol, short-chain organic acids, and hydrogen. Appl. Environ. Microbiol. 2011, 77, 1907-1909. [CrossRef] [PubMed]

73. Schink, B. Energetics of syntrophic cooperation in methanogenic degradation. Microbiol. Mol. Biol. Rev. 1997, 61, 262-280. [PubMed] 
74. Morris, B.E.L.; Henneberger, R.; Huber, H.; Moissl-Eichinger, C. Microbial syntrophy: Interaction for the common good. FEMS Microbiol. Rev. 2013, 37, 384-406. [CrossRef] [PubMed]

75. Liu, Y.; Whitman, W.B. Metabolic, phylogenetic, and ecological diversity of the methanogenic archaea. Ann. N. Y. Acad. Sci. 2008, 1125, 171-189. [CrossRef]

76. McInerney, M.J.; Sieber, J.R.; Gunsalus, R.P. Syntrophy in anaerobic global carbon cycles. Curr. Opin. Biotechnol. 2009, 20, 623-632. [CrossRef]

77. Baek, G.; Kim, J.; Kim, J.; Lee, C. Role and potential of direct interspecies electron transfer in anaerobic digestion. Energies 2018, 11, 107. [CrossRef]

78. Stams, A.; Plugge, C. Electron transfer in syntrophic communities of anaerobic bacteria and archaea. Nat. Rev. Microbiol. 2009, 7, 568-577. [CrossRef]

79. Hattori, S. Syntrophic acetate-oxidizing microbes in methanogenic environments. Microbes Environ. 2008, 23, 118-127. [CrossRef] [PubMed]

80. Westerholm, M.; Moestedt, J.; Schnürer, A. Biogas production through syntrophic acetate oxidation and deliberate operating strategies for improved digester performance. Appl. Energy 2016, 179, 124-135. [CrossRef]

81. Cazier, E.A.; Trably, E.; Steyer, J.P.; Escudie, R. Biomass hydrolysis inhibition at high hydrogen partial pressure in solid-state anaerobic digestion. Bioresour. Technol. 2015, 190, 106-113. [CrossRef] [PubMed]

82. Chen, Y.; Cheng, J.J.; Creamer, K.S. Inhibition of anaerobic digestion process: A review. Bioresour. Technol. 2008, 99, 4044-4064. [CrossRef] [PubMed]

83. Niu, Q.; Kubota, K.; Qiao, W.; Jing, Z.; Zhanga, Y.; Yu-Youa, L. Effect of ammonia inhibition on microbial community dynamic and process functional resilience in mesophilic methane fermentation of chicken manure. J. Chem. Technol. Biotechnol. 2014, 90, 2161-2169. [CrossRef]

84. Rajagopal, R.; Massé, D.I.; Singh, G. A critical review on inhibition of anaerobic digestion process by excess ammonia. Bioresour. Technol. 2013, 143, 632-641. [CrossRef] [PubMed]

85. Tian, H.; Fotidis, I.A.; Kissas, K.; Angelidaki, I. Effect of different ammonia sources on aceticlastic and hydrogenotrophic methanogens. Bioresour. Technol. 2018, 250, 390-397. [CrossRef]

86. Wrońska, I.; Cybulska, K. Quantity and quality of biogas produced from the poultry sludge optimized by filamentous fungi. Ecol. Chem. Eng. 2018, 25, 395-404. [CrossRef]

87. De Vrieze, J.; Hennebel, T.; Boon, N.; Verstraete, W. Methanosarcina: The rediscovered methanogen for heavy duty biomethanation. Bioresour. Technol. 2012, 112, 1-9. [CrossRef]

88. Meng, X.; Zhang, Y.; Sui, Q.; Zhang, J.; Wang, R.; Yu, D.; Wang, Y.; Wei, Y. Biochemical conversion and microbial community in response to ternary $\mathrm{pH}$ buffer system during anaerobic digestion of swine manure. Energies 2018, 11, 2991. [CrossRef]

89. Schnürer, A.; Nordberg, A. Ammonia, a selective agent for methane production by syntrophic acetate oxidation at mesophilic temperature. Water Sci. Technol. 2008, 57, 735-740. [CrossRef] [PubMed]

90. Klang, J.; Szewzyk, U.; Bock, D.; Theuerl, S. Nexus between the microbial diversity level and the stress tolerance within the biogas process. Anaerob 2019, in press. [CrossRef] [PubMed]

91. Lv, Z.; Leite, A.F.; Harms, H.; Glaser, K.; Liebetrau, J.; Kleinsteuber, S.; Nikolausz, M. Microbial community shifts in biogas reactors upon complete or partial ammonia inhibition. Appl. Microbiol. Biotechnol. 2018. [CrossRef] [PubMed]

92. Belostotskiy, D.E.; Ziganshina, E.E.; Siniagina, M.; Boulygina, E.A.; Miluykov, V.A.; Ziganshin, A.M. Impact of the substrate loading regime and phosphoric acid supplementation on performance of biogas reactors and microbial community dynamics during anaerobic digestion of chicken wastes. Bioresour. Technol. 2015, 193, 42-52. [CrossRef] [PubMed]

93. Gao, S.; Zhao, M.; Chen, Y.; Yu, M.; Ruan, W. Tolerance response to in situ ammonia stress in a pilot-scale anaerobic digestion reactor for alleviating ammonia inhibition. Bioresour. Technol. 2015, 198, 372-379. [CrossRef] [PubMed]

94. De Jonge, N.; Moset, V.; Møller, H.B.; Lund Nielsen, J. Microbial population dynamics in continuous anaerobic digester systems during start up, stable conditions and recovery after starvation. Bioresour. Technol. 2017, 232, 313-320. [CrossRef] [PubMed]

95. Paulo, L.M.; Stams, A.J.M.; Sousa, D.Z. Methanogens, sulphate and heavy metals: A complex system. Rev. Environ. Sci. Biol. 2015, 14, 537-553. [CrossRef] 
96. Chen, J.L.; Ortiz, R.; Steele, T.W.J.; Stuckey, D.C. Toxicants inhibiting anaerobic digestion: A review. Biotechnol. Adv. 2014, 32, 1523-1534. [CrossRef]

97. Choong, Y.Y.; Norli, I.; Abdullah, A.Z.; Yhaya, M.F. Impacts of trace element supplementation on the performance of anaerobic digestion process: A critical review. Bioresour. Technol. 2016, 209, 369-379. [CrossRef]

98. Du, L.; Liu, W. Occurrence, fate, and ecotoxicity of antibiotics in agro-ecosystems. A review. Agron. Sustain. Dev. 2012, 32, 309-327. [CrossRef]

99. Azman, S.; Khadem, A.F.; Plugge, C.M.; Stams, A.J.M.; Bec, S.; Zeeman, G. Effect of humic acid on anaerobic digestion of cellulose and xylan in completely stirred tank reactors: Inhibitory effect, mitigation of the inhibition and the dynamics of the microbial communities. Appl. Microbiol. Biotechnol. 2017, 101, 889-901. [CrossRef] [PubMed]

100. Geršl, M.; Kanduč, T.; Matýsek, D.; Šotnar, M.; Mareček, J. The role of mineral phases in the biogas production technology. Ecol. Chem. Eng. 2018, 25, 51-59. [CrossRef]

101. Yap, S.D.; Astals, S.; Lua, Y.; Peces, M.; Jensen, P.D.; Batstone, D.J.; Tait, S. Humic acid inhibition of hydrolysis and methanogenesis with different anaerobic inocula. Waste Manag. 2018, 80, 130-136. [CrossRef]

102. De Vrieze, J.; Christiaens, M.E.R.; Walraedt, D.; Devooght, A.; Ijaz, U.Z.; Boon, N. Microbial community redundancy in anaerobic digestion drives process recovery after salinity exposure. Water Res. 2017, 111, 109-117. [CrossRef] [PubMed]

103. Molaey, R.; Bayrakdar, A.; Sürmeli, R.Ö.; Çalli, B. Influence of trace element supplementation on anaerobic digestion of chicken manure: Linking process stability to methanogenic population dynamics. J. Clean. Prod. 2018, 181, 794-800. [CrossRef]

104. Seneesrisakul, K.; Sutabutr, T.; Chavadej, S. The effect of temperature on the methanogenic activity in relation to micronutrient availability. Energies 2018, 11, 1057. [CrossRef]

105. Popp, D.; Schrader, S.; Kleinsteuber, S.; Harms, H.; Sträuber, H. Biogas production from coumarin-rich plants-Inhibition by coumarin and recovery by adaptation of the bacterial community. FEMS Microbiol. Ecol. 2015, 91. [CrossRef]

106. Popp, D.; Plugge, C.M.; Kleinsteuber, S.; Harms, H.; Sträuber, H. Inhibitory effect of coumarin on syntrophic fatty acid-oxidizing and methanogenic cultures and biogas reactor microbiomes. Appl. Environ. Microbiol. 2017, 83, e00438-17. [CrossRef]

107. Mao, C.; Feng, Y.; Wang, X.; Ren, G. Review on research achievements of biogas from anaerobic digestion. Renew Sustain. Energy Rev. 2015, 45, 540-555. [CrossRef]

108. Hagos, K.; Zong, J.; Li, D.; Liu, C.; Lu, X. Anaerobic co-digestion process for biogas production: Progress, challenges and perspectives. Renew. Sustain. Energy Rev. 2017, 76, 1485-1496. [CrossRef]

109. Bouchez, T.; Blieux, A.L.; Dequiedt, S.; Domaizon, I.; Dufresne, A.; Ferreira, S.; Godon, J.J.; Hellal, J.; Joulian, C.; Quaiser, A.; et al. Molecular microbiology methods for environmental diagnosis. Environ. Chem. Lett. 2016, 14, 423-441. [CrossRef]

110. Zhang, L.; Loh, K.-C.; Lim, J.W.; Zhang, J. Bioinformatics analysis of metagenomics data of biogas-producing microbial communities in anaerobic digesters: A review. Renew. Sustain. Energy Rev. 2019, 100, 110-126. [CrossRef]

111. Bozan, M.; Akyol, Ç.; Ince, O.; Aydin, S.; Ince, B. Application of next-generation sequencing methods for microbial monitoring of anaerobic digestion of lignocellulosic biomass. Appl. Microbiol. Biotechnol. 2017, 101, 6849-6864. [CrossRef] [PubMed]

112. Cabezas, A.; Calabria de Araujo, J.; Callejas, C.; Galès, A.; Hamelin, J.; Marone, A.; Sousa, D.Z.; Trably, E.; Etchebehere, C. How to use molecular biology tools for the study of the anaerobic digestion process? Rev. Environ. Sci. Biol. 2015, 14, 555-593. [CrossRef]

113. Vanwonterghem, I.; Jensen, P.D.; Ho, D.P.; Batstone, D.J.; Tyson, G.W. Linking microbial community structure, interactions and function in anaerobic digesters using new molecular techniques. Curr. Opin. Biotechnol. 2014, 27, 55-64. [CrossRef] [PubMed]

114. Alivisatos, A.P.; Blaser, M.J.; Brodie, E.L.; Chun, M.; Dangl, J.L.; Donohue, T.J.; Dorrestein, P.C.; Gilbert, J.A.; Green, J.L.; Jansson, J.K.; et al. A unified initiative to harness Earth's microbiomes. Science 2015, 350, 507-508. [CrossRef] [PubMed] 
115. Bonk, F.; Popp, D.; Weinrich, S.; Sträuber, H.; Kleinsteuber, S.; Harms, H.; Centler, F. Intermittent fasting for microbes: How discontinuous feeding increases functional stability in anaerobic digestion. Biotechnol. Biofuels 2018, 11, 274. [CrossRef] [PubMed]

116. De Vrieze, J.; Ijaz, U.Z.; Saunders, A.M.; Theuerl, S. Terminal restriction fragment length polymorphism is an "old school" reliable technique for swift microbial community screening in anaerobic digestion. Sci. Rep. 2018, 8, 16818. [CrossRef] [PubMed]

117. Lim, J.W.; Ge, T.; Tong, Y.W. Monitoring of microbial communities in anaerobic digestion sludge for biogas optimisation. Waste Manag. 2018, 71, 334-341. [CrossRef] [PubMed]

118. Prakash, O.; Pandey, P.K.; Kulkarni, G.J.; Mahale, K.N.; Shouche, Y.S. Technicalities and glitches of terminal restriction fragment length polymorphism (TRFLP). Indian J. Microbiol. 2014, 54, 255-261. [CrossRef] [PubMed]

119. Shendure, J.; Balasubramanian, S.; Church, G.M.; Gilbert, W.; Rogers, J.; Schloss, J.A.; Waterston, R.H. DNA sequencing at 40: Past, present and future. Nature 2017, 550, 345-353. [CrossRef] [PubMed]

120. Calus, S.T.; Ijaz, U.Z.; Pinto, A.J. NanoAmpli-Seq: A workflow for amplicon sequencing for mixed microbial communities on the nanopore sequencing platform. GigaScience 2018, 7. [CrossRef]

121. Kerkhof, L.J.; Dillon, K.P.; Häggblom, M.M.; McGuinness, L.R. Profiling bacterial communities by MinION sequencing of ribosomal operons. Microbiome 2017, 5, 116. [CrossRef] [PubMed]

122. Berry, D.; Widder, S. Deciphering microbial interactions and detecting keystone species with co-occurrence networks. Front. Microbiol. 2014, 5, 219. [CrossRef] [PubMed]

123. Karimi, B.; Maron, P.A.; Chemidlin-Prevost Boure, N.; Bernard, N.; Gilbert, D.; Ranjard, L. Microbial diversity and ecological networks as indicators of environmental quality. Environ. Chem. Lett. 2017, 15, 265. [CrossRef]

124. Browne, H.P.; Neville, B.A.; Forster, S.C.; Lawley, T.D. Transmission of the gut microbiota: Spreading of health. Nat. Rev. Microbiol. 2017, 15, 531-543. [CrossRef] [PubMed]

125. Valero, A.; Rodríguez, M.-Y.; Posada-Izquierdo, G.D.; Pérez-Rodríguez, F.; Carrasco, E.; García-Gimeno, R.M. Risk factors influencing microbial contamination in food service centers. In Significance, Prevention and Control of Food Related Diseases; Makun, H., Ed.; IntechOpen: London, UK, 2016; Chapter 2; ISBN 978-953-51-2277-7.

126. Siddig, A.A.H.; Aaron, M.; Ellison, A.M.; Ochs, A.; Villar-Leemand, C.; Lau, M.K. How do ecologists select and use indicator species to monitor ecological change? Insights from 14 years of publication in Ecological Indicators. Ecol. Indic. 2016, 60, 223-230. [CrossRef]

127. Hermans, S.M.; Buckley, H.L.; Case, B.S.; Curran-Cournane, F.; Taylor, M.; Lear, G. Bacteria as emerging indicators of soil condition. Appl. Environ. Microbiol. 2017, 83, e02826-6. [CrossRef]

128. Schloter, M.; Nannipieri, P.; Sørensen, S.J.; van Elsas, J.D. Microbial indicators for soil quality. Biol. Fertil. Soils 2018, 54. [CrossRef]

129. Berg, G.; Köberl, M.; Rybakova, D.; Müller, H.; Grosch, R.; Smalla, K. Plant microbial diversity is suggested as the key to future biocontrol and health trends. FEMS Microbiol. Ecol. 2017, 93. [CrossRef]

130. Dias, T.; Dukes, A.; Antunes, P.M. Accounting for soil biotic effects on soil health and crop productivity in the design of crop rotations. J. Sci. Food Agric. 2015, 95, 447-454. [CrossRef] [PubMed]

131. Flandroy, L.; Poutahidis, T.; Berg, G.; Clarke, G.; Dao, M.-G.; Decaestecker, E.; Furman, E.; Haahtela, T.; Massart, S.; Plovier, H.; et al. The impact of human activities and lifestyles on the interlinked microbiota and health of humans and of ecosystems. Sci. Total Environ. 2018, 627, 1018-1038. [CrossRef] [PubMed]

(C) 2019 by the authors. Licensee MDPI, Basel, Switzerland. This article is an open access article distributed under the terms and conditions of the Creative Commons Attribution (CC BY) license (http://creativecommons.org/licenses/by/4.0/). 